Article

\title{
Theocentric Love Ethics
}

\section{Edward Vacek}

Religious Studies, Loyola University New Orleans, New Orleans, LA 70118, USA; evacek@loyno.edu

Received: 17 August 2017; Accepted: 7 October 2017; Published: 11 October 2017

\begin{abstract}
Joseph Selling proposes a contemporary revision of natural law ethics, making it more person-centered. Earlier James Gustafson insisted that natural law ethics was too egoist or anthropocentric, so his work proposed theocentrism as a corrective. Richard Gula in turn proposed an ethics that centers on imitating God's relationships. This essay combines the merits of all three with the author's own love-covenant basis for ethics. It contrasts secular and religious ethics, with the latter incorporating cooperation in communion with God. One strand of Aquinas's theology indicates that religious discernment is an affective process of union with God, but the typical ways of describing this union court significant dangers of reducing either God to self or self to God.
\end{abstract}

Keywords: natural law; personalism; theocentrism; love; secularism; participation; cooperation; communion; identification; discernment

"None of us lives for one's self, and no one dies for one's self, for we belong to Christ. If we live, we live for the Lord; and if we die, we die for the Lord. So, whether we live or die, we belong to the Lord". (Rom 14:7)

\section{Introduction}

As I began my career as a theologian, I was fortunate to have the famous Christian ethicist, James Gustafson, as a colleague. I was deeply influenced by a particular polemic that he, like a modern day Jeremiah, waged against any and all. One time he was asked to address senior faculty members at the University of Chicago on the topic of "Say Something Theological." This erudite author of many books announced he had a one word answer: "God," which he pronounced with a long, drawn out vowel. On other occasions, I witnessed Gustafson becoming red in the face as he argued that Christian ethics had lost its center, namely, God. Gustafson's lamented that, where once we spoke too confidently about our knowledge of God, now we hardly speak about God at all (Gustafson 1984, p. 7).

Gustafson argued, "For theological ethics ... the first task in order of importance is to establish convictions about God and God's relations to the world" (Gustafson 1984, p. 98). A common Protestant and biblical approach is to view God as Sovereign Commander, an authority whose will we must obey. Likewise one typical Catholic focus is to image God as creator whose wise design we should follow. The first has been central in Divine Command ethics and the second has been central in religious versions of Natural Law ethics (Vacek 1996). Instead, I will explore beginning with God as Lover and Covenant Partner. I develop the radical claims found in 1 John 4: "If we love one another, God lives in us, and his love is perfected in us ... God is love" (1 Jn 4: 12-16).

Joseph Selling challenges the adequacy of natural law. He proposes "that the new standard for determining this ethical language is the human person, integrally and adequately considered" (Selling 2016, pp. 10, 131, 146; Selling 1999, p. 60). Selling sets down the foundation of ethics in the following way: "What is good is ultimately what is good-for-the person and what is evil ultimately is evil-for-the-person, integrally and adequately considered" (Selling 2016, p. 146). By contrast, for Gustafson, "The general answer to the moral question from a theocentric perspective is that "we are to relate ourselves and all things in a manner (or in ways) appropriate to their relations to God" 
(Gustafson 1984, pp. 1-2). Richard Gula presents a third view, "Imitating [God's] faithful love which binds the covenant together is the moral imperative for living" (Gula 1989, p. 97). I propose a new standard. The criterion for determining right from wrong is what befits the love covenant we have with God and with one another. The difference between my own view and that of Selling is the centrality of God, and the difference between my view and that Gustafson is the centrality of love (Gustafson 1981, p. 236). I modify Gula's point to insist that we not only imitate God's love, we also participate in God's love. This is theocentric love ethics.

\section{Theocentrism}

Gustafson's disputatious goal was "to propose an alteration of the egocentric, anthropocentric concern of Christian piety and Christian theology" (Gustafson 1981, p. 110). These are real targets. Moral theologians have, for example, read Genesis 1:28 to claim that all other creatures exist simply for human purposes. Catholic Church teaching, such as in Populorum Progressio (Paul VI 1967, pp. 15-16), says "human fulfillment constitutes, as it were, a summary of our duties." Spiritual writers encourage a good relationship with God as a way of attaining our own fulfillment. Likewise our culture promotes "self-maximizers" (Smedes 1983, p. 160).

Our biblical and ecclesial traditions, in contrast, assume and assert that we are "covenant-keepers" (Smedes 1983, p. 160). That means our own human fulfillment is not our primary duty. Jesus says that those who lose their life for his sake will gain their lives. But the life gained is not earthly fulfillment. As Adrian Thatcher writes, "Christology precedes ethics and shapes it." He adds, "Following Jesus is worked out in relation to his sacrificial death on the Cross" (Thatcher 2007, p. 53). Even more expansively, the Biblical tradition invites us to locate ourselves within God's covenantal history. From "In the beginning when God ... " (Gen 1:1) to "Amen. Come Lord Jesus" (Rev. 22:20), our moral task is to carry out our role within this history. What is ultimately good is not what is good for us, but good for God's ongoing covenant with creation.

Theocentrism is full of theological challenges. For example, the Catholic Church has condemned those who argue that we should love God purely for God's own sake (Denzinger 1957, \#1327, 1329, 1331, 1348). To the contrary, Anders Nygren argued that we should not love God at all because such love is so self-centered. Metaphysically grounded theologians such as Aquinas allow for us to center our lives on God, but argue that God's aseity and immutability makes any mutual relationship impossible (Vacek 1994). Even the term "center" is problematic because it obscures God's transcendence, that is, God is not one being-however central-among other beings.

To many people, theocentrism seems superfluous for moral living. We can live our individual lives and we can form groups as if there is no God. As individuals, our goal may be to "find our authentic self." As social beings, we must find our place within our groups and then preserve and develop them. Ordinarily, as Selling notes, our daily moral task is just to deal appropriately with the many different kinds of situations in which we find ourselves. Accepting our "multidimensionality implies de-centring the person, both individually and collectively" (Selling 2016, pp. 156, 167).

Nevertheless, theocentrism additionally demands that our ultimate evolving horizon should be God's kingdom. As covenantal partners we should seek to carry out our role in God's world. We are, of course, ordinarily the person most responsible for developing our own selves and the groups we belong to. But our greatest significance lies in the ways that we make a unique, appropriate contribution to God's project. Needless to say, for most if not all of us, actively centering our lives on God is an ever changing activity. It tends to be episodic. Extending episodes into a consistent pattern is sainthood. Gula aptly describes the ideal of this covenant: "with God as the center of value for us, we need to see all things in their relation to God and to integrate all things into our love of God" (Gula 1989, p. 317).

\section{Membership}

Christians have often employed the analogy of the Body of Christ, of which each of us is a member. A more contemporary analogy for God's kingdom is that of a corporation, since this allows for greater 
autonomy of the members. Members are the free source of their own activity, but their activity also belongs to the corporation. Within a large corporation's employee flow chart, each of us is related to everyone else in the firm, though often in highly circuitous and tenuous ways. We are not the center of the corporation, though we may be central in some subgroup. The corporation has a mission that is affected by and affects every member. "Put very generally, the well-being of the whole has to be taken into account not only for the sake of the parts but for the 'system,' and the interactions of the parts greatly affect the whole" (Gustafson 1984, p. 16).

To stretch the analogy a bit further, all of us members have direct as well as mediated access to the head of the corporation. Stretched even further, we are or should be bound by love instead of contracts we have rationally agreed upon. If this or that member leaves the corporation, it continues to exist. Put more generally, participation signals a union in which its members are both independent of and dependent on the union that unites them. Their union both differentiates them and is differentiated by their membership.

Given human limitations such as embodiment, each of us can and often does tend to look upon all else as if we are the center. Nevertheless, we are also able to take up the perspectives of others, and our hearts can feel what other people feel. Each of us can realize that we are not the center of the world, but only a tiny, tiny, tiny part of that world. When we are forgetful of this participation in the lives of other people, we live a shrunken life. Since, by God's grace, we also participate in God, we can, somewhat, see the world from God's perspective. When we are forgetful of our participation in God, the core of a finally meaningful life is hollowed rather than hallowed.

When we take up God's perspective, we realize that the God who is love is concerned for the fulfillment, as much as is finitely possible, of each of us and of the whole and its members. To be creator, redeemer, and sanctifier, God must love each creature and each group of creatures. Of course, the identity of God is not exhausted in these relationships, since God is also related to God and is transcendent to creation. Thus, theocentric love should be directed not only to God in relation to the world but also to God as wholly Other. That participation of God in us and we in God greatly magnifies and alters our role. We are stagehands in God's worldly drama, and that is a great privilege. We are worshipers of the transcendent God, and this is holy mystery.

\section{Secular and Religious Living}

Selling argues that a "personalist ethics does not have to be religious." But, he adds, "there is no inherent difficulty in introducing religious language into a system that claims an openness to the whole of reality and the ultimate connectedness of every dimension of that reality" (Selling 1999, p. 65). Presumably, Selling does not mean to suggest that we simply add language. Instead, I am arguing, the addition of a reference to God should radically revise the project of ethics and of moral living.

Charles Taylor in his magisterial book, A Secular Age (Taylor 2007), has alerted us to the way secularism now does not refer to a battle between theists and atheists. Rather it refers to a relegation of God talk and God belief to the private sphere. Some people go to Church on Sunday and some people go bowling; both are equal, optional, private choices; and their respective value claims are not worth arguing about. In this cultural context, Selling is understandably hesitant to name God, since talk of God tends to drive people away from the conversation (Selling 2016, p. 135). Nevertheless, it is insufficient to appeal only to "our human destiny" or to "being caught up in a project that is universal and greater than any individual imagination" (Selling 2016, pp. 136-37).

As I have noted, we do many, many things in our lives without experiencing any relationship to any ultimate destiny or project. Other animals get along without experiencing these ultimates, and we are animals. Similarly, most of our thinking and loving and willing can take place in biological, psychological, or spiritual (mental) realms without being religious. That is, the reference of these acts is ourselves and aspects of our world, without even tacit reference to God as Horizon or Ground.

We can possess a secular attitude that has solely secular goods. Our secular age contains many people who claim to have no relationship to God. They experience no affection towards God. They do 
not intend to live consonantly with God. Rather, they simply want to do good (Gustafson 1981, p. 227). Many even do far more good than those who want to be in relationship with God but who, for various reasons, including weakness and sin, do not live out that desire. Nevertheless, it is one thing to be a decent human being and it is another to act intentionally and freely in union with God. Anonymous Christians may de facto contribute to God's mission; but such persons are religious only when they act out of a self-transcendence that intends God. Absent that intentionality, at least in an implicit form, their activity bears no religious merit (Aquinas 1948, [hereinafter ST] II-II.27.7).

Still the inclusion of religious intentionality does make a difference in our lives. Aquinas notes that civic virtue is an imperfect virtue when it does not take place within our affirmation of God. Indeed, Aquinas stipulates that no strictly true virtue is possible without the agent's union with God (ST II-II.23.7). Although Selling rejects the thesis that "ordinary virtue" is perfected by charity (Selling 2016, p. 152), I suggest that the difference that charity makes is that the ordinary virtue becomes part of our personal relationship to God. Just as a solitary walk in the park is different from a walk with a friend, so too our awareness of God's presence changes the meaning of our lives. In this sense, charity perfects the ordinary virtue by making it an aspect of our relationship to God. In this sense, charity is the source of "true" virtue.

In religious experience, we can move from creatures to God and from God to creatures. God and creatures can be experienced simultaneously ("mediated immediacy") or sequentially. Aquinas rightly argued that love for God does not necessarily include love of our neighbor and that love of neighbor or self does not necessarily include love of God (ST II-II.27.8.). Still, love of God inclines us to love ourselves and our neighbors as an enactment of our friendship with God. And love of self and neighbor can incline us to love God.

Love of self and neighbor is sometimes described as loving others for God's sake, and that can be appropriate (ST II-II.23.1 \& 25.8). There is, however, a difference between, on the one hand, loving a stranger for God's sake, that is, as a way of pleasing or showing love to God and, on the other hand, loving the stranger in consonance with God's love for the stranger. With the latter, we love in union with God's love, not mainly as a way of affirming God, but as a way of further cooperating with God who loves the stranger through us. Cooperation involves union not replacement. Similarly, there is a difference between, on the one hand, loving our neighbors by affirming their inclination to love God (ST II-II.25.2) and, on the other hand, loving them as actual or potential members of God's covenanted community to which they and we belong.

\section{Communion and Cooperation with God}

For Aquinas, "the end of all human actions and affections is the love of God, whereby principally we attain to our last end" (ST II-II.27.6). One very strong strand of Aquinas' thought is anthropocentric. (Below I will emphasize a more distinctly Christian strand.) I want to eschew Aquinas's anthropocentrism by changing the last part of that claim to read: whereby principally we cooperate with God in living out our covenant with God and creation. The change is from eros to philia. Loving God as communing with God shifts our intention from our own self to our friendship or covenant with God.

Love does involve a change in ourselves (ST I-II.28.2 \& 5), but its primary movement is to unite with the beloved. We share in-sometimes we say we identify with-the beloved and in so doing we ourselves participate in the beloved's dynamism. To use Aquinas's metaphysical language, the beloved's form becomes "the form of the lover." Aquinas then argues that, since "each thing acts according to the demands and needs of its form, which is the principle of action and the rule of operation" (Aquinas 2008, p. 121), we therefore act in accord with the dynamism of the beloved. Thus, when we love God we are animated to participate in the creative, redeeming, and sanctifying power of God. We can and should enter into God's practical life, allowing ourselves to unite with the various activities of God, such as God's creativity, God's forgiveness, and God's love. Aquinas describes this union: "Therefore through love, the lover becomes one with the beloved, which is made the form of the lover" (Aquinas 2008, p. 121). A more contemporary way to make the same claim is that, when we 
enter the mind and heart and will of God, this union will reshape or wither many of our current loves. This is a process of conversion, growth in holiness, and cooperation.

I agree with Selling that Aquinas's description of this process as an infusion of virtue seems gratuitous (ST II-II.24.3). We can preserve Aquinas's anti-Pelagian point by noting that the experience of love is one of evocation (Jn 6:44). Love for God depends on God's invitation. Like all emotions, love for God cannot be simply willed by us; rather it arises in relating us to its object and is dependent on that object. The distinctive character of our loves depends on the type of object we love. When the "object" is God, we have a religious love. What is distinctive about Judeo-Christian charity is that its "object" is God inviting us into sharing a covenant (ST II-II 23.5). What is distinctive about a specifically Christian charity is our participation in Christ's new covenant.

\section{Religious Discernment}

Love moves us to know those, including God, whom we love. As Aquinas wrote: "the lover is not satisfied with a superficial apprehension of the beloved, but strives to gain an intimate knowledge of everything pertaining to the beloved" (ST I-II.28.2).

When our loves are in order, they do much the work of ethical discernment. Aquinas notes, "love is a certain harmony of the appetite with that which is apprehended as suitable; while hatred is dissonance of the appetite from that which is apprehended as repugnant and hurtful" (ST I-II.29.1). Thus, harmony or lack of harmony between our affections and God provides the primordial basis for discerning what is to be done and to be avoided.

When we love God with genuine charity, Aquinas argues, there is a certain connaturality between God's affections and our own (ST I-II.62.3). This connaturality is crucial for a properly Christian moral life. It enables us to make judgments in light of God's involvement in our lives and the world (ST II-II.45.4.). Aquinas writes, "Now rectitude of judgment is twofold: first, on account of the perfect use of reason, secondly, on account of a certain connaturality with the matter about which one has to judge." His example is somewhat surprising to our sex-obsessed age. He says that many people have to use reason equipped with a set of norms in order to act chastely. But a virtuously chaste person just feels what is appropriate without reflection. He adds, "Now this sympathy or connaturality for divine things is the result of charity which unites us to God" (ST II-II.45.2). This wisdom born of union with God can "direct us not only in contemplation but also in action" (ST II-II.45.3).

Aquinas argues that, for a Christian, the key to being in concert with God is not primarily reason, but sharing in God's wisdom (ST II-II.24.1). Aquinas adds, however, when this love is enacted in this world, this union with God must then be combined with reason in order to make good practical decisions (ST II-II.27.6). Such decisions are not purely reasonable, nor are they immediately given as part of union with God. Rather they are a product of both. In this, Aquinas offers parallels with St. Ignatius's three modes of discernment (Ignatius 1959).

What happens in discernment is communication (ST II-II.23.1). It is part of charity that we explicitly direct ourselves to God and that we experience the world about us as related to God (ST II-II.26.13). The communication might occur through scripture or tradition, but primarily it is a communication of self-God's self to us and our self to God. As Selling observes, this communication or grace is best understood not as a thing but as the offer and acceptance and enactment of a relationship with God (Selling 2016, p. 90). We can, if we so will, accept God's love, that is, God's desire to be interior to our lives, shaping and forming us (Vacek 2015).

\section{Dangers of Identification}

In this last section, I need to warn of significant dangers in stressing affective union with God as central and disclosive of our moral obligations. Love, I have argued, is an affective form of participation, of unity-in-difference. Desiring to highlight the union that is distinctive of love, people tend to overlook the way love also preserves and highlights the differences between the lover and the beloved. For example, Aquinas emphasizes union (ST I-II.26.2), but he describes this in a way that makes love 
of another to be a form of self-love: "looking on his friend as identified with himself" (ST I-II.28.2). He notes that we love others as if they are ourselves, but he forgets to highlight the otherness of the friend or enemy.

There are two common mistakes when difference is obscured by union. In a pious expression, we hear it said that it is God, not our selves, who act. St. Paul writes, "it is no longer I who live, but it is Christ who lives in me" (Gal 2:20). In a contrary expression, humans are all too ready to claim that what is good for them is good for others. "Do to others as you would have them do to you; for this the law and the prophets" (Mt 7:12). Psychologists regularly counsel that one of the mistakes in life is to love another as our self. A year after our marriage, for example, we rudely become aware that our spouses are quite different from us. We often have to affirm in them what we would not and should not affirm in ourselves. The shellfish they enjoy would kill us. In this sense, we are to love our neighbor not as ourselves but as one who is different from ourselves. More to the present theme, we can share in some of God's love and activity, but we are not God and God is not us. God needs us to do what cannot happen without our cooperation, for example, "make love" with our spouse. But God's concerns often and properly are beyond what should be our concerns.

Again, Aquinas argues that love is based on likeness (ST I-II.27.3), and that is true enough. But it is also based on difference; the attraction of the sexes would otherwise not happen. Furthermore, if God loves us, then, other matters being equal, God affirms our freedom and wants us to make our own decisions. Paradoxically, when we center our lives on a covenant with the God who loves us, we enter into a union that can and usually must affirm our own semi-independence or autonomy. Likewise, but more so, we affirm God's otherness. God wills the good of all creation and of God's own self, and thus commonly God's overall will may be incompatible with our appropriate wants or needs. Centering our lives on God may lead to disassociating ourselves from what we reasonably want for ourselves and for others we love. The tragic story of Abram and Isaac explores this possibility. Jesus, who tells his disciples, "I will do whatever you ask in my name" (Jn 14:13), also says, "Father, if you are willing, remove this cup from me; yet, not my will but yours be done" (Lk 22:42).

The problem of justifying self-sacrifice for another further exposes this tension between theocentrism and self-fulfillment. Due perhaps to his Aristotelean background, Aquinas has a difficult time explaining why lovers give their lives for one another. In his view, a friend "does not will the good of his friend more than his own good" (ST I-II.28.3). By contrast, Jesus assures us that friends in fact do this (Jn 15: 13). They sacrifice their lives for the sake of the lives of their friends. Aquinas's explanation that friends may be giving up their bodily life but what they really intend is to choose their own growth in virtue fails to appreciate the hearts of those who have made such sacrifices. In many senses, Jesus did not live a fulfilling life. In contrast to an Aristotlean ethic, Jesus did not focus on his own flourishing. Rather, as Selling well notes, he focused on the reign of God that was aborning in the people around him (Selling 2016, pp. 205-7). Similarly, Gustafson nobly writes: "the reason for self-denying actions is that they serve the ends and purposes in particular circumstances that one (or a community) judges to be consonant with God's purposes" (Gustafson 1984, p. 139). Ordinarily, God's purposes include our own earthly fulfillment, so that fulfillment is one of our chief responsibilities. Still, the basic end of human life is to love God within a covenant with God, not to fulfill oneself. Fulfilling our love covenant with God is the meaning of Christian life. Both self-denial and self-fulfillment may be consonant with that relationship. After loss or death, resurrection, one hopes, will follow.

\section{Christocentric Coda}

What further specifies Christian ethics? Selling rightly answers that we should "be attentive to the teaching and life-example, the lifeways, of the Lord himself" (Selling 2016, p. 200). But more than this is needed. Ethics is Christian when we not only learn from Christ but we love him and in that love begin to love in union with him. We participate in, not just learn from, Christ's life (Thatcher 2007, p. 216). But, again, since our union with Jesus includes difference, we love in our own distinctive way. In fact, Jesus said we will do greater things than he actually did (Jn14:12). 
Selling asks, What is theological about theological ethics? (Selling 2016, pp. 45, 200). My answer is love of God. "For, 'In him we live and move and have our being' ... We are God's offspring" (Acts 17:28).

Conflicts of Interest: The author declares no conflict of interest.

\section{References}

Aquinas, Thomas. 1948. Summa Theologica. 5 vols. Westminster: Christian Classics.

Aquinas, Thomas. 2008. On Love and Charity: Readings from the "Commentary on the Sentences of Peter Lombard". Translated by Peter A. Kwasniewski, Thomas Bolin, and Joseph Bolin. Washington: Catholic University of America.

Denzinger, Heinrich. 1957. Enchiridion Symbolorum. Edited by Peter Huenermann. St. Louis: B. Herder.

Gula, Richard. 1989. Reason Informed by Faith. New York: Paulist.

Gustafson, James. 1981. Ethics from a Theocentric Perspective Volume 1. Chicago: University of Chicago.

Gustafson, James. 1984. Ethics from a Theocentric Perspective Volume 2. Chicago: University of Chicago.

Ignatius. 1959. The Spiritual Exercises of St. Ignatius. Translated by Louis J. Puhl. Westminster: The Newman Press.

Paul, VI. 1967. Populorum Progressio. Available online: http:/ /w2.vatican.va/content/paul-vi/en/encyclicals/ documents/hf_p-vi_enc_26031967_populorum.html (accessed on 10 October 2017).

Selling, Joseph. 1999. Is a Personalist Ethic Necessarily Anthropocentric? Ethical Perspectives 1: 60-66. [CrossRef] Selling, Joseph. 2016. Reframing Catholic Theological Ethics. Oxford: Oxford University.

Smedes, Lewis. 1983. Mere Morality: What God Expects from Ordinary People. Grand Rapids: Eerdmans.

Taylor, Charles. 2007. Secular Age. Cambridge: Harvard University.

Thatcher, Adrian. 2007. Theology and Families. Malden: Blackwell.

Vacek, Edward. 1994. Love Human and Divine: The Heart of Christian Ethics. Washington: Georgetown University.

Vacek, Edward. 1996. Divine-Command, Natural-Law, and Mutual-Love Ethics. Theological Studies 57: 633-53. [CrossRef]

Vacek, Edward. 2015. Grace is the Emotion of Love of God. Journal of Moral Theology 4, \#2: 63-88.

(C) 2017 by the author. Licensee MDPI, Basel, Switzerland. This article is an open access article distributed under the terms and conditions of the Creative Commons Attribution (CC BY) license (http:// creativecommons.org/licenses/by/4.0/). 